\title{
硫化銀抵抗素子を用いた直列点灯方式
}

\author{
専門会員 阪口忠雄* 専师会員 野口 透** 夏临会員 西村肇祐*** \\ 正会員 加賀山 明*** 渡辺耕造***
}

\section{Series Operating Circuit of Lamps Using Silver Sulphide Resistor}

Tadao Sakaguchi (Fellow Member), Toru Noguchi (Fellow Member)

(Kyoto University)

Keisuke Nishimura (Fellow Member), Akira Kagayama (Member) and Kozo Watanabe

(Seiwa Electric Machine Co. Ltd.)

\begin{abstract}
Silver sulphide $\left(\mathrm{Ag}_{2} \mathrm{~S}\right)$ is an ionic bond crystal with phase transition temperature of $179^{\circ} \mathrm{C}$. At this temperature, the resistivity of $\mathrm{Ag}_{2} \mathrm{~S}$ changes discontinuously to an extent as large as $10^{3}$. In $\beta$ phase $\left(<179^{\circ} \mathrm{C}\right), \mathrm{Ag}_{2} \mathrm{~S}$ behaves as a semiconductor just like the conventional thermistor. In $\alpha$ phase $\left(>179^{\circ} \mathrm{C}\right)$, the conduction of $\mathrm{Ag}_{2} \mathrm{~S}$ is metallic, and its resistivity is very low.

The silver sulphide resistor can be applied to a device for shorting out a faulty lamp of series operating circuit by taking advantage of the resistance change at the phase transition.

In this paper, this characteristics of series circuit using this device are described.

The merits of this circuit are as follows:

(1) This circuit is available for discharge lamps as well as incandescent lamps.

(2) The constant current regulator is not required in this circuit.

(3) The silver sulphide resistor can be used for a fail shorting device repeatedly.
\end{abstract}

\section{1. 緒言}

道路照明あるいは飛行場照明などにおいて，多数の電 球または放電灯を長区間にわたって点灯する場合に，直， 列点灯方式が採用されることがあるが，この方式の最大 の火点は回路中の 1 灯が故障して消灯すると, その回路 の全灯が消えてしまうため, 保安上重大な支障をきたす ことである.この久点を防ぐために，従来フィルムカッ トアウトを各ランプに並列に入れる方法や，一次側を直 列接続した絶縁トランスを介して各ランプを点灯する方 法などによって, 故障ランプ以外のシンプの点灯を維持

* 京都大学工学部

** 京都大学工学研究所

$* * *$ 星和電機林
する方式が考觉られている゙

篗者らは，これらのう式をは罢なった新しいう式とし て，きわめて大きな领の抵抗温度係数を有する硫化銀抵 抗素子を川い，これによって故障ランプに流れるべき電 流の局代わりをさせる直列点灯方式について, 基礎的な 研究を行なったので，これを報告する。

\section{2. 硫化銀抵抗素子の電気的特性}

硫化銀は $179^{\circ} \mathrm{C}$ に変態点を有し，この温度以上では $\alpha-\mathrm{Ag}_{2} \mathrm{~S}$ ，この滥度以下では $\beta-\mathrm{Ag}_{2} \mathrm{~S}$ となり，その結 晶棈造は $\alpha-\mathrm{Ag}_{2} \mathrm{~S}$ が休心立力 $j$ 晶系（格子常数: $a=$ $4.88 \AA$ ),$\beta-\mathrm{Ag}_{2} \mathrm{~S}$ が単斜晶系（格子常数: $a_{0}=4.32 \AA$, $\left.b_{0}=6.93 \AA, c_{0}=7.86 \AA \AA \Omega=99.61^{\circ}\right)$ であることが知 られている2). 
硫化銀はこの変態点を境にして, 絬晶構造が変化する と同時にその電気的特性も大きく变化する.すなわち $\beta$ $-\mathrm{Ag}_{2} \mathrm{~S}$ は一般の半導体の抵抗温度特性々同様に, 㑔の 抵抗温度係数を有する特性を示し，しかもその温度係数 は金属酸化物系のサーミスタよりも大きいという特徴を 有している。それに対し， $\alpha-\mathrm{Ag}_{2} \mathrm{~S}$ は金属的な特性を 有し, 変態点を境にして, 抵抗率の值そのものが急激に 約 3 桁低下して，きわめて低い抵抗摔值になるとともに その抵抗温度係数も正の小さな詣となる。

\section{$2.1 \mathbf{A g}_{2} \mathrm{~S}$ の抵抗一温度特性}

硫化銀抵抗素子の代戈的な抵抗一滥度特性を図 1 に 示す。変態温度以下の $\beta$ 相では, 半涪休特有の伿の抵抗

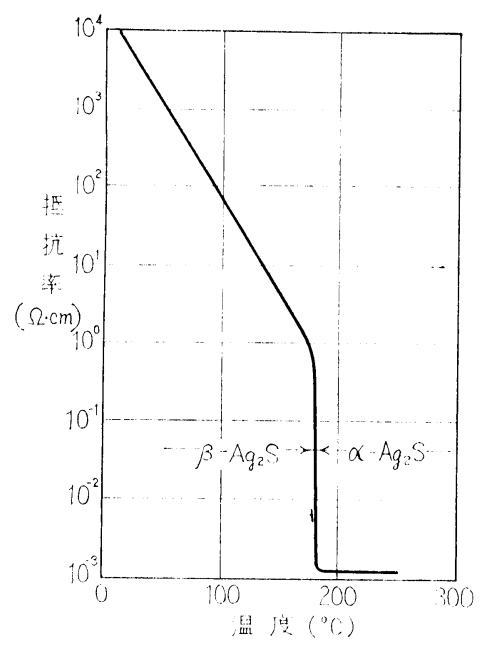

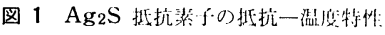

温度係数を有し，その值は室温付近で約 $1 \times 10^{-1} /{ }^{\circ} \mathrm{C}$ と なり, 普通のサーミスタの数倍の温度係数を有してい る.さらに変態温度に沶いて抵抗值はイ連綍的に約 3 析 減少し，それ以上:の温度頒域では $\alpha-\mathrm{Ag}_{2} \mathrm{~S}$ となって， $10^{-3} \Omega \cdot \mathrm{cm}$ 程度のきわわて低い抵抗滋と小さな正の温度 係数を有する金属的な伝敷を示すようになる32.

以上の特性から明らかな上りに，硫化銀抵抗猄了は温

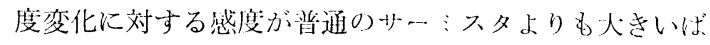
かりでなく，変態温度以上の $\alpha-\mathrm{Ag}_{2} \mathrm{~S} に$ にいては，金 属材料に近い高導電度を有するため, 低滥状態では汪と んど電流が流れないが, 变態温度以上の尚温になると, 導通状態になるという特殊な目的に使用することが叮能 になる。

ただし，硫化銀抵抗素子の利用に際し注意しなケれば ならないことは, $\beta-\mathrm{Ag}_{2} \mathrm{~S}$ の懸電機構がイオン伝導であ るため, 直流で使用すると分極を生じ，その特性が不安 定となるといらことである.したがって硫化銀抵抗素子 は交流回路においてだけ使用することができる.

\section{$2.2 \quad \mathbf{A g}_{2} \mathrm{~S}$ の電圧一電流特性}

$\mathrm{Ag}_{2} \mathrm{~S}$ に通電した場合，電流密度が小さい間は抵抗值 は変化しないが, 電流が大きくなるにつれて, ジュール 熱に上り素子自体の温度が上算し，それにつれて抵抗值 が下がるため, 普通のサーミスタの場合と同様, 図 2 に

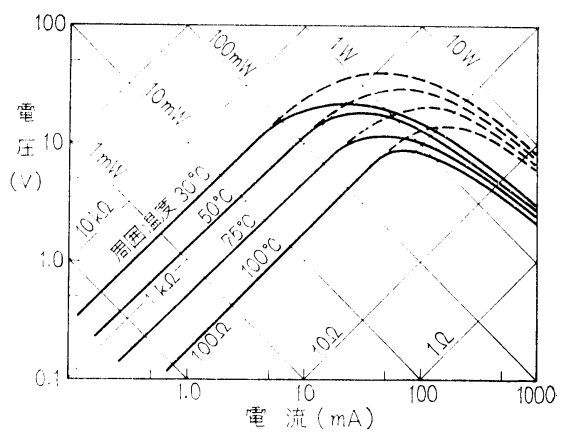

図 $2 \mathrm{Ag}_{2} \mathrm{~S}$ 抵抗素子の電在:一需流特性

亦すような独特な電圧一電流特性を示し, 特性曲線はピ 一ク值を過ぎて只のこう配となる。

この特性は素子自体の温度が関係しているので, 周囲 温度や放熱板の影響を受ける. 図 2 の実線で示した曲線 は周囲温度をいろいろ变えた場合の直径 $6 \mathrm{~mm}$, 長さ $30 \mathrm{~mm}$ の円筒形の $\mathrm{Ag}_{2} \mathrm{~S}$ 抵抗素子の電圧一電流特性を 示したもので, 当然のことながら，周囲温度が低い注 ど, 特性曲線のピークは高くなる。亦た図 2 の点線で示 した曲線は上の素子を八つに切断し, それぞれの切断素 子の間に, $25 \mathrm{~mm}$ 平方の正方形の 銅板より成る放熱板 7 枚をはさんで組み立てた放熱板つきの $\mathrm{Ag}_{2} \mathrm{~S}$ 抵抗素子 の電圧一電流特性を示したものである。これより明らか なように, 電流密度の小さな間は, 放熱板の影響はない が，電流密度が大きくなり，ジュ一ル熱汇よる $\mathrm{Ag}_{2} \mathrm{~S}$ の 自己発熱が生じ，温度が上昇するよらになると，放熱板 の効果が現われ，特性曲線のピークは放熱板のない場合 に比べると高くなる ${ }^{4) 5}$.

図 2 は両対数目盛で表わされているので, この図で右 ばがりの $45^{\circ}$ の直線を引けげ抵抗一定の線となり，右下 ボりの $45^{\circ}$ の直線をひけば消費電力一定の線となる. 図 には，それぞれの自線に対応する抵抗值およびッット数 が併記されている。この図より明らかなように, 放熱板 をつけたものの汪らが, 電力容量を数倍大きくすること ができる.

\section{3 温度サイクルによる硫化銀抵抗素子の変形}

$\mathrm{Ag}_{2} \mathrm{~S}$ は変態の際に結晶構造が変化するため, 変態温 度の上下に多数回加熱, 冷却をくり返すとしだいに変形 する・たと党ば真空溶製法により作製した多結晶質の純 料の $\mathrm{Ag}_{2} \mathrm{~S}$ より成る抵抗素子を, $20 \sim 230^{\circ} \mathrm{C}$ の温度範团 で 1, 000 回程度加熱・冷却をくり返すと, ほとんど原形 


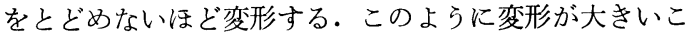
とはその電気的特性を变化させたり, リード線の脱落を 生じさせたりするので, $\mathrm{Ag}_{2} \mathrm{~S}$ の応用上きわめて大きな 障害となり，これをなんらかの法で押えないかぎり， $\mathrm{Ag}_{2} \mathrm{~S}$ の電父的特性がいかにすぐれていても, その実用 化は不可能といわなければならない。

そこで筆者らは, $\mathrm{Ag}_{2} \mathrm{~S}$ の変形を押学る一つの方法と して, $\mathrm{Ag}_{2} \mathrm{~S}$ と二相合金を形成することができる金属, あるいは金属間化合物で, かつ $\mathrm{Ag}_{2} \mathrm{~S}$ 抵抗素子の使用 温度範囲で変態点をもたない材料, たとえば $\mathrm{Sb}_{2} \mathrm{~S}_{3}$ や $\mathrm{Bi}_{2} \mathrm{~S}_{3}$ などを適当量添加し, 二相合金として $\mathrm{Ag}_{2} \mathrm{~S}$ 中に 分散させる方法を考案した．これら添加物は相転移を行 なわないため，ほとんど変形しないから，これが二相合 金全体の変形を押える役目を果たすことになる，したが ってこのような二相合金の $\mathrm{Ag}_{2} \mathrm{~S}$ 抵抗素子では, たとえ ば 10,000 回程度の加熱・冷却のサイクルをくり返して も, その形状にはほとんど変形が認められないことが, 実験的にも明らかになっている.

このように $\mathrm{Ag}_{2} \mathrm{~S}$ 二相合金を形成する添加物を $\mathrm{Ag}_{2} \mathrm{~S}$ に混合すると変形を押えることができるが，添加物の影 響により抵抗素子全体の電気的特性は, 純粋の $\mathrm{Ag}_{2} \mathrm{~S} の$

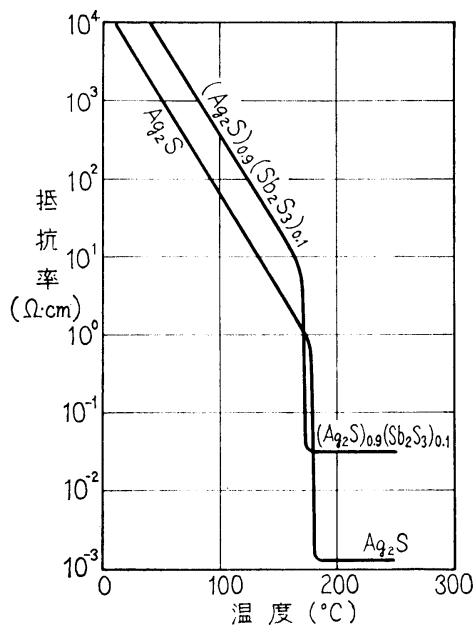

図3 純 $\mathrm{Ag}_{2} \mathrm{~S}$ と $\left(\mathrm{Ag}_{2} \mathrm{~S}\right)_{0.9}\left(\mathrm{Sb}_{2} \mathrm{~S}_{3}\right)_{0.1}$ 二相合金の抵抗一温度特性:

それに比べると多少変化する.図 3 はその一例として, 純粋の $\mathrm{Ag}_{2} \mathrm{~S}$ と $\left(\mathrm{Ag}_{2} \mathrm{~S}\right)_{0.9}\left(\mathrm{Sb}_{2} \mathrm{~S}_{3}\right)_{0.1}$ の二相合金との抵 抗温度特性を示したものである.この図より明らかなよ うに, $\mathrm{Ag}_{2} \mathrm{~S}$ に添加物として $10 \%$ 程度の $\mathrm{Sb}_{2} \mathrm{~S}_{3}$ を添加 した場合には，抵抗一温度特性は添加物の影響により抵 抗率の值そのものは多少変わるが，特性曲線の形そのも のは本質的には純 $\mathrm{Ag}_{2} \mathrm{~S}$ の場合とそれほど差異はなく， かつ熱サイクルによる変形も押えることができるので, 実用上きわめて有効であるということができる.
ただし，添加物の量をあまり多くすると，添加物のも つ電気的特性の影響が大きくなり, 図 1 あるいは図 3 の ような $\mathrm{Ag}_{2} \mathrm{~S}$ 本来の特性が隐されることがあるので, 添 加量については十分注意する必要がある.

\section{3. 硫化銀抵抗素子を用いた 白熱電球の直列点} 灯

\section{1 従来の直列点灯方式}

直列点灯力式はランプを直列に接続して, これに定電 流電源により電流を流してランプを点灯する方式で, 従 来広く用いられていた直列点灯方式は大別すると，フィ ルムカットアウトを用いる方式と, 絶縁トランスを用い る方式とである。

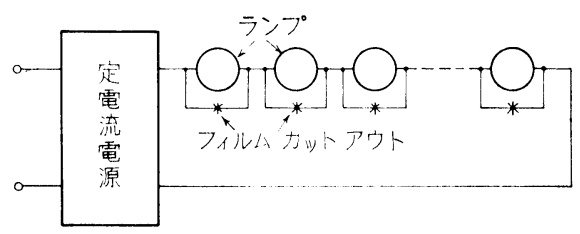

図 4 フィルムカットフウトを用いる直列点灯回路

フィルムカットアウトを用いる直列点灯方式の回路図 は图 4 に示すと扣りで, 定電流電源を通して直列に接 続された各ランプに，それぞれ並列にフィルムカットア ウトを接続したものである.このフィルムカットアウト の働きは, もし点灯中のランプの 1 灯が消えた場合, 瞬 間的にその故障ランプに並列にそう入されたフィルムカ ットアウトに高圧が印加され，これが絶縁破壊して短絡 するため回路がしゃ断されず, 残りのランプが点灯状態 を持続できるようにすることである。

この方式は簡単であるが，次のような欠点をもってい る.フィルムカットアウトは一度動作すると再使用でき ないため，そのたびごとに取り替える必要があるし，ま たランプが白熱電球の場合は確実に動作するが，放電灯 の場合は，フィルムカットアウトが動作する前に残りの 放電灯が消灯してしまうと，フィルムカットアウトに高 圧が印加されなくなるため，フィルムカットアウトが働 かない場合が出てくる.さらにこの方式ではランプに直 接高圧がかかるため, ランプおよび照明器具の絶縁に注 意を要するとともに保安も危険である。

絶縁トランスを用いる方式は図 5 に示すように, 絶

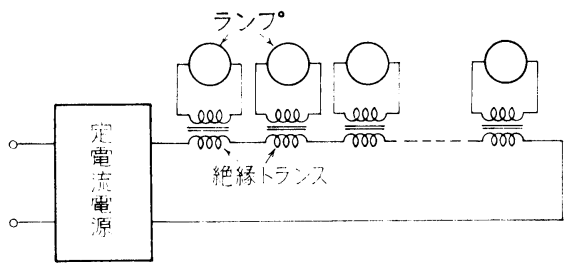

图 5 紿䋎トランスを用いる置列点灯回路 
縁トランスの一次側を直列に接続し，その二次側にラン プを接続する方式である. この方式では絶縁トランスの 二次側は低圧となり, 照明器具も一般用のものがそのま ま使えるし，保守も安全であるままた故障ランプができ た場合も，トランスの一次側が直列に接続されているた め, 残りのランプの点灯にはなんら支障がなく, 放電灯 の直列点灯にも利用できる。しかしその反面，1灯ごと に絶縁トランスを必要とするため, 一般的に経費が高く なる欠点がある。

\section{$3.2 \mathbf{A g}_{2} \mathrm{~S}$ 抵抗素子を用いた白熱電球の直列点灯}

$\mathrm{Ag}_{2} \mathrm{~S}$ は自己発熱により, 図 2 に示したような電压一 電流特性をるつことはすでに説明したとおりであるが， この特性を利用して，直列点灯されたランプの 1 灯が敌 障して消灯したとき，その故障ランプの后代わりを $\mathrm{Ag}_{2} \mathrm{~S}$ 抵抗素子にやらせることにより，残りのランプの

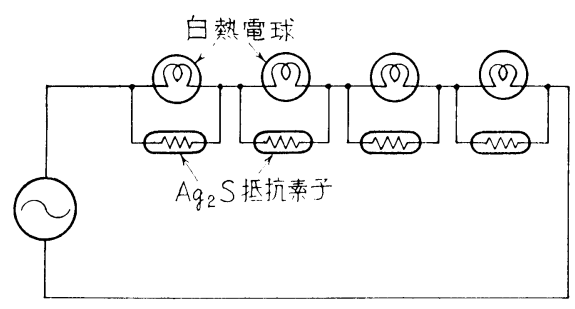

图 $6 \mathrm{Ag}_{2} \mathrm{~S}$ 抵抗絜年を朋いた白熱電球の 列列点灯回路

点灯を維持することができる．図 6 はこの方式による 白熱電球の直列点灯回路の回路図で, 直列に按続された 電球のおの括のに, 適当な特性をもった $\mathrm{Ag}_{2} \mathrm{~S}$ 抵抗素子 が並列に接続されている.

筆者らは，この回路の基本的な動作特性を検討するた めに, $100 \mathrm{~V}, 100 \mathrm{~W}$ の電球 4 灯を電源電圧 $400 \mathrm{~V}$ で值 列点灯した場合について実験した. 図 7 はこの実験に

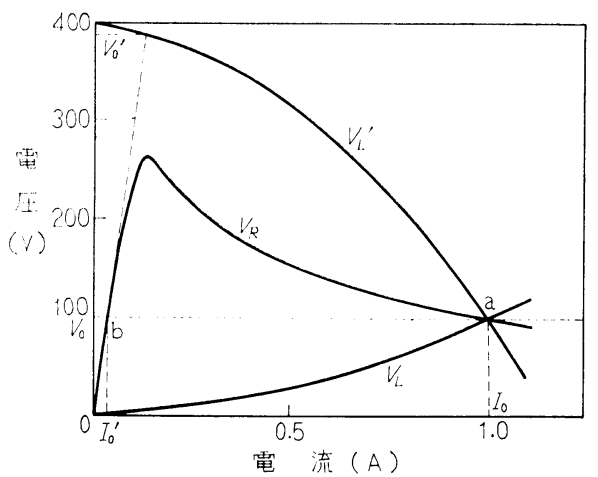

图 $7 \mathrm{Ag}_{2} \mathrm{~S}$ 抵抗素子を朋いた白熱電球值 列点灯回路の動作特件:

基づく動作原理の説明図である.曲線 $V_{L}$ は電球 1 灯分 の電圧一電流特性, $V_{L}^{\prime}$ は電源電压を一定にしておい て, 回路中の電灯 1 灯（故障電球に相当する電球）を可
変抵抗で置換した場合の可変抵抗の両端にかかる電圧と 回路を流れる電流との関係を表わす特性曲線, $V_{R}$ は $\mathrm{Ag}_{2} \mathrm{~S}$ 抵抗素子の電压一電流特性を示している。な抏こ の場合, $\mathrm{Ag}_{2} \mathrm{~S}$ 抵抗素子の特性曲線は同図点 $\mathrm{a}$ で示され るように電球の定格電流值 $I_{0}$ に执いて, 特性曲線 $V_{R}$, $V_{L}, V_{L}{ }^{\prime}$ が交わるよらに設汁されていることが必要で ある。

回路中のすべての電球が正常に点灯している場合に は, 各電球には定格電圧 $V_{0}$ がかかり, 定格電流 $I_{0}$ が 流れている。また各電流に並列に接続されている $\mathrm{Ag}_{2} \mathrm{~S}$ 抵抗素子にも当然電压 $V_{0}$ がかかるから, 電球が正常に 点灯している間は, $\mathrm{Ag}_{2} \mathrm{~S}$ 抵抗素子に流れる電流は図の 点 bに相当する電流值 $I_{0}^{\prime}$ であって，この值はきわめて 小さく, これによる電力損失はほとんど無視できる程度 である。

次に回路中の電球が 1 灯断線した場合を考兄る. 断線 の瞬間, その電球に並列に接続された $\mathrm{Ag}_{2} \mathrm{~S}$ 抵抗素子に は, その瞬間の $\mathrm{Ag}_{2} \mathrm{~S}$ の抵抗值に対応して図 7 の $V_{0}^{\prime}$ と いら電圧が印加される.この電圧は図の $V_{R}$ 曲線に比べ て高いため, $\mathrm{Ag}_{2} \mathrm{~S}$ の加熱に有効に働き， $\mathrm{Ag}_{2} \mathrm{~S}$ 抵抗素 子は急速に自己発熱を行ない, その抵抗值を変化しなが ら, 曲線 $V_{R}$ と $V_{L}{ }^{\prime}$ との交点 a まで急速に動作点が移動 し, a 点に至って安定状態に達する. その結果, 断線し た電球の代わりに $\mathrm{Ag}_{2} \mathrm{~S}$ 抵抗素子が置き代わって動作 し, 残りの健全な電球に正常時の定格電流を流すように なる.この間の移行時間はきわめて短く, 電球が 1 灯断 線し, $\mathrm{Ag}_{2} \mathrm{~S}$ 抵抗素子が動作を開始してから, 残りの電 球が正常の点灯状態に復帰するまでに要する時間は, $0.01 \sim 0.05$ 秒程度である.

以上が $\mathrm{Ag}_{2} \mathrm{~S}$ 抵抗素子を用いた新しい直列点灯方式の 動作原理であるが，この方式の特徴は次のと括りであ る.

(1) $\mathrm{Ag}_{2} \mathrm{~S}$ 抵抗素子が完全に故障電球の肩代わりをす るため, 定電流電源を用いなくても，故障時においても 回路には定格電流が流れる.

（2）故障電球を交換すると, $\mathrm{Ag}_{2} \mathrm{~S}$ 抵抗素子は自動的 に正常動作状態に復帰寸るため, 何回でもくり返し使用 することができる.

(3) フィルムカットアウトと違い，放電灯に対しても 確実に作動させることができる.

(4) フィルムカットアウト方式と同様，ランプに直接 高圧がかかる欠点があるため, ランプおよび照明器具の 絶縁ならびに保安に注意を要する.

\section{4. 硫化銀抵抗素子を用いた放電灯の直列点灯}

\section{1 けい光灯の直列点灯 ${ }^{6}$ )}

けい光灯の直列点灯回路に扮いても, 白熱電球の直列 


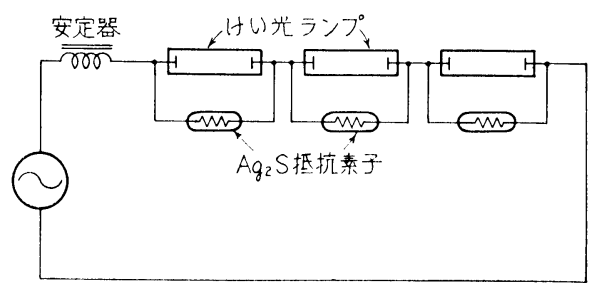

图 $8 \mathrm{Ag}_{2} \mathrm{~S}$ 抵抗素子を用いたけい光灯の 㨁列点灯回路

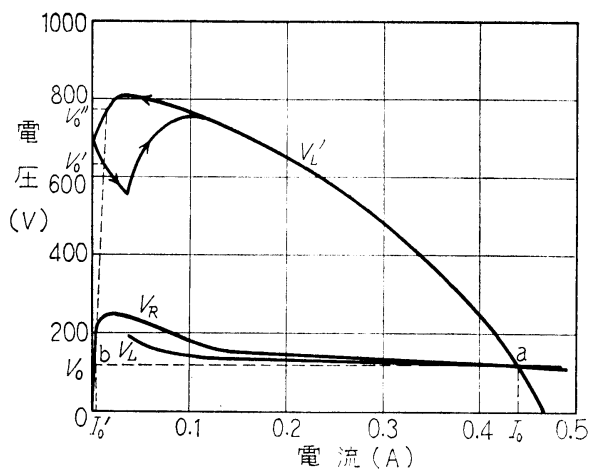

图 $9 \mathrm{Ag}_{2} \mathrm{~S}$ 抵抗素子を用いたけい炕灯直 列点灯回路の動作特件:

点灯回路の場合と同様, $\mathrm{Ag}_{2} \mathrm{~S}$ 抵抗素子によって故障ラ ンプの補償をさせることが可能である. $40 \mathrm{~W} け い$ 光ラ ンプ 3 灯を電源電圧 $1,000 \mathrm{~V}$ で, 実験的に直列点灯した 場合の点灯回路を 図 8 に，その動作特性曲線を図 9 に示す.

図 9 の各特性曲線の付号は図 7 の場合と同様で, 曲線 $V_{L}$ はけい光ランプ1灯分の電流一電圧特性, $V_{L^{\prime}}$ は電 源電圧を一定にしておいて, 回路中のけい光ランプ 1 灯 を可変抵抗で置換したときの可变抵抗の電流一電圧特 性, $V_{R}$ は $\mathrm{Ag}_{2} \mathrm{~S}$ 抵抗素子の電流一電圧特性を示してい る. 図 7 と異なる点は, けい光ランプの電流一電圧特性 が白熱電球の電流一電圧特性と異なるため, 動作特性が 多少複雑になることである.すなわち曲線 $V_{L}{ }^{\prime}$ が電流 值の少ない領域で, 電流の減少時々増大時とで, たどる 曲線が違ってくる.この原因は電流の減少時はアーク放 電のままでけい光ランプが消灯するまで電流が減少する が, 増大時にはグロー放電の形で始動した後, アーク放 電に移行するためである。

けい光ランプが 1 灯故障して点灯しなくなった場合の $\mathrm{Ag}_{2} \mathrm{~S}$ 抵抗素子の動作原理は, 白熱電球の直列点灯の場 合と同じであるが，けい光ランプが 1 灯消灯した瞬間 に，それに並列にそう入した $\mathrm{Ag}_{2} \mathrm{~S}$ 抵抗素子にかかる電 圧が，残りのけい光ランプがいったん全部消灯してしま らか, あるいは消灯するまでには至らないかによって, 図 9 の電圧 $V_{0}^{\prime}$ または $V_{0}^{\prime \prime}$ の值になる点が, 白熱電球
の場合と多少異なっている.しかし，いずれの值の電圧 がかかったにしても，それ以後は白熱電球の場合と同 様, $\mathrm{Ag}_{2} \mathrm{~S}$ 抵抗素子の自己発熱による抵抗変化のため, 回路電流は漸次增大して定格電流 $I_{0}$ に落ち着く．ただ $V_{0}^{\prime}$ がかかるか $V_{0}^{\prime \prime}$ がかかるかによって違う点は, それ により $\mathrm{Ag}_{2} \mathrm{~S}$ 抵抗素子の自己発熱量が異なるため, けい 光ランプが故障後, 定常状態を回復するまでの時間が多 少違うということだけである。

次にこの故障ランプ補償用に使用する抵抗素子は，必 ずしも全部を $\mathrm{Ag}_{2} \mathrm{~S}$ にする必要はなく，場合によって は, $\mathrm{Ag}_{2} \mathrm{~S}$ 抵抗素子と二クロム線のような通常の抵抗材 料を直列に接続したものであってもさしつかえない.上

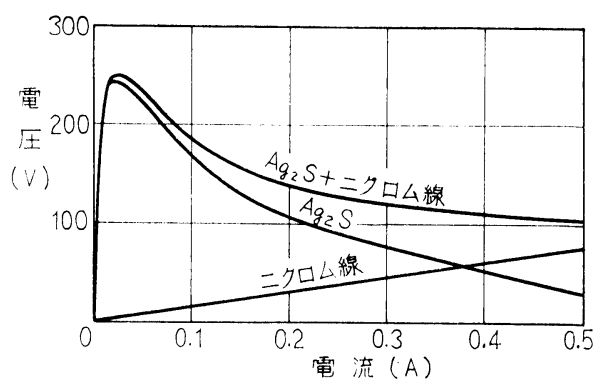

图 $10 \quad \mathrm{Ag}_{2} \mathrm{~S}$ と二クロム線との淔列姜繥の 合成抵抗素子の電流一電LE特件:

記実験に使用した抵抗素子も， $\mathrm{Ag}_{2} \mathrm{~S}$ とニクロム線とを 直列接続したもので, その扔の扔のの電流一電圧特性は 図 10 に示すと扣りで, 要するにその合成した特性が定 格電流值において，けい光ランプの定格ランプ電圧に一 致するように設計されて打ればよい。これにより $\mathrm{Ag}_{2} \mathrm{~S}$ の使用量を節約することができ, 経済的な見地より有効 な手段と考兄られる。

\section{2 水銀灯の直列点灯 ${ }^{\text {? }}$}

けい光灯の直列点灯の場合は, けい光ランプが 1 灯故 障したために，残りの全灯がいったん消灯したとして も, 直ちに再点灯し, $\mathrm{Ag}_{2} \mathrm{~S}$ 抵抗素子の働きにより故障 ランプ以外は定常状態が回復されるから問題はないが, 水銀灯の場合には, 定常状態で点灯している水銀ランプ がいったん消灯すると, 発光管内の水銀宿㸚圧が高压で あるため, ランプが冷却されて低温に戻るまで再始動し ない。したがって水銀灯の值列点灯回路においては，1 灯が故障して消灯したとき, 残りの水銀ランプが消弧し ない間に $\mathrm{Ag}_{2} \mathrm{~S}$ 抵抗素子が動作して, 故障ランプの肩代 わりをして定格状態を回復することが必要である。とこ ろが一方, 水銀ランプが消弧する電流值はけい光ランプ などの場合に比べると, かなり大きな值であるため, 水 銀灯直列点灯回路に対しては, 故障ランプ補償素子を多 少工夫する必要がある.图 11 は実験的に $40 \mathrm{~W}$ 水銀ラ 


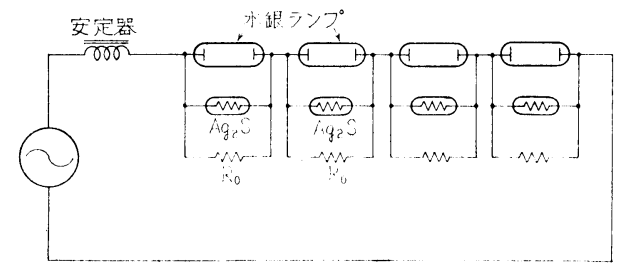

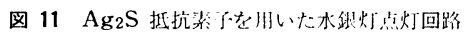

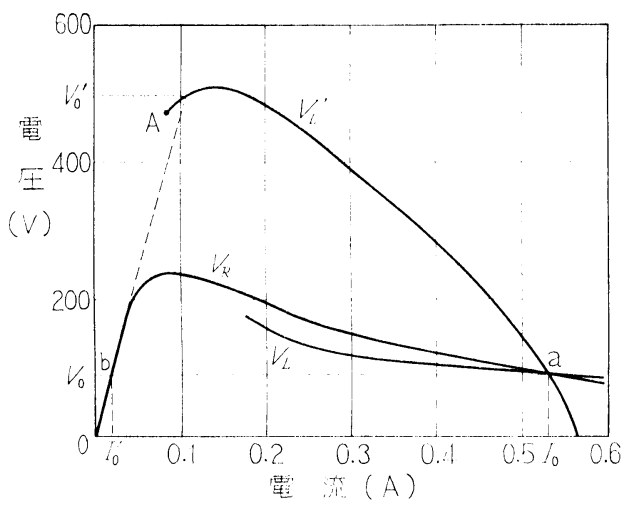

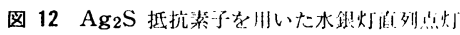
回路の動作特州:

ンプ 4 灯を電源電圧 $800 \mathrm{~V}$ で直列点灯した場合の回路 を，図12 はそのときの動作特性を示している. 図11の 抵抗 $R_{0}$ が水銀ランプの消弧を防ぐためにそら入した固 定抵抗である．次にその働きを述べる。

䦸12の特性曲線 $V_{L}, V_{L}{ }^{\prime}, V_{R}$ は国 9 の埸命之同じ意 味をもったものであるが，故障ランプの代わりに可変抵 抗を置換した場合の特性曲線 $V_{L}{ }^{\prime}$ が，点 A で消失して いることがけい光ランプの場合と違っている．この点が 水銀ランプが 1 灯故障したとき, 残りのランプの電流が 減少してて, 消弧するに至る限界の電流值を与兄る点であ る.したがって水銀ランプ1灯が故障した橓閂に，これ に並列に接続した補償用の $\mathrm{Ag}_{2} \mathrm{~S}$ 抵抗烮子に流れる電流 が，点 A に対㐫する電流よりも大きくなければならな い。この条件を図12で具体的に説明すると，水銀シンブ が 1 灯消灯した瞬間に $\mathrm{Ag}_{2} \mathrm{~S}$ 抵抗素子に流れる笔流上,

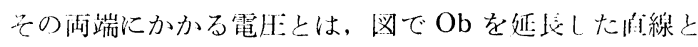
特性曲線 $V_{L}{ }^{\prime}$ との交点に対応する電流・電愔で少えられ る.したがって，直線 $\mathrm{Ob}$ と特性曲線 $V_{L^{\prime}}$ とが交点をも つことが，残りの水銀ランプを消弧させないための条件 である。

もし直線 $\mathrm{Ob}$ が，図で点 $\mathrm{A} よ り$ 左にきて交点をもたな い場合には，残りの水銀ランプはいったん消弧してしを うので，直線 $\mathrm{Ob}$ をっと寝かせて特性: 曲線 $V_{L^{\prime}}$ と交点 をもつよらにする必要がある。その働きをするものが业 列に入れた固定抵抗 $R_{0}$ である.すなわち電流の少ない
領域では固定抵抗 $R_{0}$ の抵抗值がきいて, $\mathrm{Ag}_{2} \mathrm{~S}$ と $R_{0}$ との合成抵抗值は下がり, 直線 $\mathrm{Ob}$ は寝てくるが, 電流 の多い領域では $\mathrm{Ag}_{2} \mathrm{~S}$ の抵抗が非常に小さくなり, 並列 に入れられた固定抵抗 $R_{0}$ の影響は注とんど無視できる ようになる。図12の特性曲線 $V_{R}$ はこの $\mathrm{Ag}_{2} \mathrm{~S}$ 抵抗素了. 之固定抵抗 $R_{0}$ との前列问路の合成抵抗の電流一電压特 性を示している.

な抢ここでは， $\mathrm{Ag}_{2} \mathrm{~S}$ 抵抗素子の低電流領域での特性 曲線を寝かせるために，固定抵抗 $R_{0}$ を用いる場合につ き説明したが，固定抵抗の代和りに適当な值のインダリ タンスやコンデンサを用いても同様な効果が得られる.

以上のような工夫をすることにより，水銀灯の直列点 灯回路に打いて子容易に, かつ確実に故障ランプの補償 を行ならことができる。な扔不幸にして $\mathrm{Ag}_{2} \mathrm{~S}$ 抵抗素子 が瞬間的に故障ランプの肩代わりをすることに失敗し て, 残りの全ランプが消弧した場合でも, これらの水銀 ランプが冷えて再始動が可能な状態にまで達すれば, 自 動的に再始動し, 故障ランプに並列にそう入した $\mathrm{Ag}_{2} \mathrm{~S}$ 抵抗素子も自動的に動作して, 補償の役目を果たすこと はいうまでもないことである。

\section{5. 結言}

以上は敌障ランプの補償用として，きわめて大きな真 の抵抗温度係数をもつ硫化銀抵抗素子を用いた新しい直 列点灯方式について，基礎的な実験を行なった結果を報 售したものであるが, 硫化銀抵抗素子の特徵として, 変 態温度以下では高抵抗であるが，変態温度以上になると 金属に近い導電性を有するようになるといら特性を利用 して, 自熱電球, けい光灯, 水銀灯などの直列点灯回路 に打いて, 故障ランプが生じた場合, 硫化銀抵抗素子が 白動的に動作して，残りのランプが消灯するのを防ぐよ うにした回路であって，フィルムカットアウトや絶縁卜 ランスを用いる従来の直列点灯方式に比べると, 次の涂 点が特に違っている。

（1）自熱電球はもちろんのこと，以い光灯，水銀灯な どの放電灯の直列点灯回路にも利用でさる。

（2）硫化銀抵抗素子が完全に故障シンプの筒代わりを 与るので, 定電流電源を使用になくても战障時にも回路 に定格電流が流れる。

(3) 硫化銀抵抗素子の自己発䓡による抵抗一温度特性 を利用しているので, 何回でもくり返し使用が可能で, 故障ランプを交換すれば，硫化銀抵抗素子は自動的に正 常動作状態に復帰する.

なおこの垁験では，この新しい直列点灯方式の基本的 な特性を求めるために, 比較的に実験しやすい小容量の ランブを数灯直列に点灯した場合について実験したが，

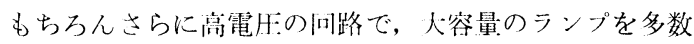


直列点灯する実用的な点灯回路に適用することが，十分 可能であることはいらまでもないことである.

最後に本研究に使用した硫化銀抵抗素子は, 京都大学: 丁学部治金学教室村上陽太郎教授の研究室之, 筆者らの 協同研究の成果によるものであることを付記し，深謝の 意を表する次第である。

\section{参 考 文 献}

(1) M.E. Robertson: Illum. Engng 55 (1960) 87

(2) ASTM Cards : 11-688 (1961) 735
（3）阪口ほか：第10回応物連大（昭38）259

（4）野口, 渡辺, 阪口：電気四学会連大（昭40） 1712

(5) T. Sakaguchi and T. Noguchi : Tech. Reports of Eng. Res. Inst. Kyoto Univ., Report No. 119 (1965)

(6) 野口, 渡辺, 加贸川, 畒村, 阪口：電父関係学会 関西支部連大（炤39） 199

（7）阪口，野口，渡辺：電'社関係学:会関酉支部連大， (

（受付1969位：5月16日，而受付同年：8月 5 日）

\begin{tabular}{|c|c|c|c|c|c|}
\hline 巻 & 号 & ページ & 行 & 识 & Il: \\
\hline \multirow[t]{7}{*}{53} & 6 & 288 & 16 & $F_{3}=\alpha \rho^{2} \rho_{1} \rho_{2} F\left[1-k\left(1-\rho_{2}\right]+(1-\alpha) \rho^{2} \rho_{1} F\lceil 1\right.$ & $F_{3}=\alpha \rho^{2} \rho_{1} \rho_{2} F\left\lceil 1-k\left(1-\rho_{2}\right)\right]+(1-\alpha) \rho^{2} \rho_{1} F\lceil 1$ \\
\hline & & 288 & 20 & $f_{3}=\tau \alpha \rho^{2} \rho_{1} F\left[1-k\left(1-\rho_{2}\right]\left[1-\alpha\left(1-\rho_{2}\right)\right.\right.$ & $f_{3}=\tau \alpha \rho^{2} \rho_{1} F\left|1-k\left(1-\rho_{2}\right)\right|\left[1-\alpha\left(1-\rho_{2}\right)\right\rceil$ \\
\hline & & 290 & 6 & $\Delta_{3}=\frac{\left(E / E_{0}\right)}{\left(\rho_{1} / \rho_{2}\right)}-1=\cdots \cdots \cdots$ & $\Delta_{3}=\frac{\left(E / E_{0}\right)}{\left(\rho_{1} / \rho_{0}\right)}-1=\cdots \cdots \cdots$ \\
\hline & & 290 & 沷 8 & $\varepsilon($ deqs. $)$ & $\varepsilon$ (degs.) \\
\hline & & 291 & $\left(\begin{array}{c}14 \\
(\text { 式(7)) }\end{array}\right.$ & $\cdots \cdots \cdots+[1+K(i, i)] E_{i}+$ & $\cdots \cdots \cdots+[1+K(i, i)] E_{i}+\cdots \cdots \cdots$ \\
\hline & & 291 & 下 3 & $\xi=n \times 10^{\circ}$ & $\zeta=n \times 10^{\circ}$ \\
\hline & & 292 & 下 5 & (July. 1, 1968) & (July 1, 1968) \\
\hline
\end{tabular}

